\title{
Edukasi 10 Indikator Perilaku Hidup Bersih dan Sehat (PHBS) Tatanan Rumah Tangga di SMA Korpri Kota Banjarmasin
}

\author{
Norfai ${ }^{1}$, Eddy Rahman ${ }^{2}$, Khairul Anam ${ }^{3}$ \\ ${ }^{1-3}$ Fakultas Kesehatan Masyarakat Universitas Islam Kalimantan (UNISKA) MAAB Banjarmasin \\ Email: norfai92@gmail.com
}

Submitted :17/06/2020

Accepted: 01/07/2020

Published: 24/11/2020

\begin{abstract}
The purpose of this community service activity is to increase students' knowledge about the 10 indicators of Clean and Healthy Behavior household arrangements. Counseling uses media power points, but before starting counseling, questionnaires are filled out by students (pretest). Counseling is carried out by lecture, discussion and question and answer methods, then after counseling, the questionnaire is distributed again to be filled out by students (posttest), after knowledge data before and after counseling has been obtained, then the data analysis using Wilcoxon statistical test. Based on the results of community service activities at the KORPRI senior high school in Banjarmasin, the p-value $(0,000)<\alpha(0.05)$ means that there is a significant difference in knowledge between before and after counseling using power point media, thus it can be concluded that the counseling method uses media power point conducted at the KORPRI senior high school in the city of Banjarmasin is able and successful in increasing students' knowledge about the 10 indicators of Clean and Healthy Behavior household arrangements. It is recommended that schools can work together with the Public Health Services in the region in order to empower school health unit (UKS) to be able to educate school health unit members who are tasked with providing health education using the media, especially power point media in order to help provide comprehensive understanding for other students about health through school health unit at the KORPRI senior high school in Banjarmasin.
\end{abstract}

Keywords: knowledge, PHBS household arrangements, student

\begin{abstract}
Abstrak
Tujuan dari kegiatan pengabdian ini adalah untuk meningkatkan pengetahuan siswa mengenai 10 indikator Perilaku Hidup Bersih dan Sehat (PHBS) tatanan rumah tangga. Penyuluhan menggunakan media power poin, akan tetapi sebelum memulai penyuluhan, dilakukan pengisian kuesioner oleh siswa (pretest). Penyuluhan dilaksanakan dengan metode ceramah, diskusi serta tanya jawab, kemudian setelah diberikan penyuluhan, maka dibagikan kembali kuesioner tersebut untuk diisi kembali oleh siswa (posttest), setelah data pengetahuan sebelum dan sesudah penyuluhan sudah didapatkan, maka dilakukan analisis data menggunakan uji statistik wilcoxon. Berdasarkan hasil kegiatan pengabdian di SMA KORPRI kota Banjarmasin menunjukkan bahwa $p$-value $(0,000)<\alpha(0,05)$ yang artinya terdapat perbedaan pengetahuan yang bermakna antara sebelum dan sesudah penyuluhan menggunakan media power point, dengan demikian dapat disimpulkan bahwa metode penyuluhan menggunakan media power point yang dilakukan di SMA KORPRI kota Banjarmasin mampu dan berhasil meningkatkan pengetahuan siswa mengenai 10 indikator Perilaku Hidup Bersih dan Sehat (PHBS) tatanan rumah tangga. Disarankan agar pihak sekolah dapat bekerjasama dengan pihak Puskesmas yang ada di wilayah tersebut dalam rangka memberdayakan UKS untuk dapat mendidik anggota UKS yang bertugas dalam memberikan edukasi kesehatan menggunakan media, khususnya media power point agar dapat membantu memberikan pemahaman bagi siswa yang lainnya mengenai kesehatan secara komprehensif melalui UKS di SMA KORPRI kota Banjarmasin.
\end{abstract}

Kata Kunci: pengetahuan, PHBS tatatan rumah tangga, siswa 


\section{PENDAHULUAN}

Pada tahun 2011 telah dibuat indikator PHBS yang baru dan sedikit berbeda dengan indikator PHBS ditetapkan sebelumnya. Indikator PHBS yang ditetapkan pada tahun 2011 oleh Pusat Promosi Kesehatan Kementerian Kesehatan mencakup 10 indikator yang meliputi :1) Persalinan ditolong oleh tenaga kesehatan; 2) melakukan penimbangan bayi dan balita; 3) memberikan ASI eksklusif; 4) penggunaan air bersih; 5) mencuci tangan dengan air bersih dan sabun; 6) memberantas jentik nyamuk; 7) memakai jamban sehat; 8) makan buah dan sayur setiap hari; 9) melakukan aktivitas fisik setiap hari; 10) tidak merokok dalam rumah. Pada PHBS tahun 2013 untuk rumah tangga dengan balita digunakan 10 indikator, sehingga nilai tertinggi adalah 10; sedangkan untuk rumah tangga tanpa balita terdiri dari 7 indikator, sehingga nilai tertinggi adalah tujuh. Penilaian PHBS rumah tangga baik diukur dengan batasan yang sama dengan penilaian rumah tangga PHBS tahun 2007. Kriteria rumah tangga dengan PHBS baik adalah rumah tangga yang memenuhi indikator baik, sebesar 6 indikator atau lebih untuk rumah tangga yang punya balita dan 5 indikator atau lebih untuk rumah tangga yang tidak mempunyai balita (Balitbangkes Kemenkes RI, 2013).

Masalah pertolongan persalinan oleh tenaga kesehatan yang belum mencapai target menjadi salah satu faktor utama tingginya angka kematian ibu (AKI) di Indonesia. Cakupan penolong persalinan sangat penting dengan memperhatikan seberapa banyak persalinan yang dapat ditangani, khususnya oleh tenaga kesehatan. Indikator ini masih menjadi indikator proksi kematian ibu (AKI) yang penting. Salah satu tujuan pembangunan millennium development goals (MDGs) adalah meningkatkan kesehatan ibu dengan menurunkan angka kematian ibu sebesar tiga perempatnya pada tahun 2015 dari kondisi tahun 1990 dengan salah satu indikatornya adalah proporsi pertolongan persalinan oleh tenaga kesehatan terlatih (Mpembeni, et.al., 2007 dalam Rahman, 2016).

Pada tahun 2018 terdapat $90,32 \%$ persalinan yang ditolong tenaga kesehatan. Sementara ibu hamil yang menjalani persalinan dengan ditolong oleh tenaga kesehatan di fasilitas pelayanan kesehatan sebesar 86,28\%. Dengan demikian masih terdapat sekitar 16\% persalinan yang ditolong tenaga kesehatan namun tidak dilakukan di fasilitas pelayanan kesehatan (Kemenkes RI, 2019).Berdasarkan data Kalimantan Selatan menyatakan bahwa cakupan ibu bersalin di fasilitas kesehatan pada tahun 2017 sebesar 85,1\% (2.478 keluarga) sedangkan pada tahun 2018 sebesar $89,07 \%$ (14.756 keluarga), data ini membuktikan bahwa adanya kenaikan persentase yang belum signifikan pada ibu hamil dalam memilih penolong persalinan di fasilitas kesehatan (Pusdatin Kemenkes RI, 2019).

Air Susu Ibu (ASI) eksklusif berdasarkan Peraturan Pemerintah Nomor 33 Tahun 2012 tentang Pemberian Air Susu Ibu (ASI) Eksklusif adalah ASI yang diberikan kepada bayi sejak dilahirkan selama enam bulan, tanpa menambahkan dan atau mengganti dengan makanan atau minuman lain (kecuali obat, vitamin, dan mineral) (Kemenkes RI, 2019). Secara nasional, cakupan bayi mendapat ASI eksklusif tahun 2018 yaitu sebesar $68,74 \%$. Angka tersebut sudah melampaui target Renstra tahun 2018 yaitu $47 \%$. Persentase tertinggi cakupan pemberian ASI eksklusif terdapat pada Provinsi Jawa Barat $(90,79 \%)$, sedangkan persentase terendah terdapat di Provinsi Gorontalo $(30,71 \%)$. Sebanyak enam provinsi belum mencapai target Renstra tahun 2018 (Kemenkes RI, 2019). Berdasarkan data 
di Kalimantan Selatan didapatkan bahwa cakupan bayi yang diberi ASI eksklusif selama 6 bulan mengalami penurunan persentase yaitu pada tahun 2017 sebesar 79,4\% (3.075 keluarga) sedangkan pada tahun 2018 sebesar $77 \% \quad(17.930$ keluarga) (Pusdatin Kemenkes RI, 2019).

$\begin{array}{ccr}\text { Posyandu } & \text { sebagai } & \text { wadah } \\ \text { pemantauan } & \text { pertumbuhan }\end{array}$
perkembangan anak melalui grafik berat badan dan mencatatnya pada KMS. Kartu Menuju Sehat yang diisi lengkap oleh kader bisa dijadikan indikator bahwa anak rajin dibawa ke posyandu. Semakin rajin anak dibawa ke posyandu, maka keadaan tumbuh kembangnya semakin terkontrol dan lebih cepat dilakukan penanggulangan apabila tumbuh kembang anak terhambat. Beberapa hal yang dapat menghambat tumbuh kembang anak di antaranya dikarenakan kurang gizi atau penyakit tertentu pada anak (Hs, Hastaty, dkk., 2015).

Pada tahun 2018, persentase ratarata balita umur 6-59 bulan yang ditimbang di Indonesia yaitu 68,37\% anak per bulan. Persentase tertinggi terdapat di Provinsi Bali yaitu sebesar $84,71 \%$, sedangkan persentase terendah terdapat di Provinsi Kalimantan Tengah yaitu sebesar $32,51 \%$. Sebanyak empat provinsi belum melaporkan datanya, yaitu Provinsi Papua, Papua Barat, Maluku, dan Nusa Tenggara Barat (Kemenkes RI, 2019).Berdasarkan data di Kalimantan Selatan didapatkan bahwa cakupan pertumbuhan Balita dipantau tiap bulan sebesar 80,2\% (10.661 keluarga) pada tahun 2017, sedangkan pada tahun 2018 sebesar 80,49\% (65.002 keluarga), berarti adanya kenaikan persentase yang belum signifikan terhadap pemantauan pertumbuhan Balita secara berkala (Pusdatin Kemenkes RI, 2019).

Cuci tangan pakai sabun sebagai upaya preventif dalam melindungi diri dari berbagai penyakit menular. Cuci tangan menggunakan sabun dapat kita lakukan pada waktu-waktu berikut: sebelum menyiapkan makanan, sebelum dan sesudah makan, setelah BAK dan $\mathrm{BAB}$, setelah membuang ingus, setelah membuang dan atau menangani sampah, kemudian setelah bermain/memberi makan/memegang hewan, serta setelah batuk atau bersin pada tangan kita. Cuci tangan pakai sabun yang dipraktikkan secara tepat dan benar merupakan cara termudah dan efektif untuk mencegah berjangkitnya penyakit. Mencuci tangan dengan air dan sabun dapat lebih efektif menghilangkan kotoran dan debu secara mekanis dari permukaan kulit dan secara bermakna mengurangi jumlah mikroorganisme penyebab penyakit seperti virus, bakteri dan parasit lainnya pada kedua tangan. Mencuci tangan dengan menggunakan air dan sabun dapat lebih efektif membersihkan kotoran dan telur cacing yang menempel pada permukaan kulit, kuku dan jari-jari pada kedua tangan (Desiyanto dan Djannah, 2012 dalam Risnawaty, 2016).

Bedasarkan data Riset Kesehatan Dasar tahun 2018 didapatkan bahwa proporsi perilaku benar dalam mencuci tangan yaitu cuci tangan pakai sabun dengan air mengalir sebelum menyiapkan makanan, setiap kali tangan kotor (memegang uang, binatang dan berkebun), setelah Buang Air Besar (BAB), setelah menceboki bayi/anak, setelah menggunakan pestisida/insektisida, sebelum menyusui bayi, dan sebelum makan pada penduduk umur $\geq 10$ tahun menurut Provinsi Kalimantan Selatan sebesar $51,7 \%$. Proporsi perilaku benar dalam dalam cuci tangan pada penduduk umur $\geq 10$ tahun menurut karakteristik kelompok umur 1519 tahun sebesar 47,2\% sedangkan kelompok umur 20-24 tahun sebesar $50,4 \%$. Hal ini mengindikasikan bahwa kelompok remaja masih rendah kesadarannya dalam mencuci tangan 
pakai sabun dengan air mengalir (Balitbangkes Kemenkes RI, 2018).

Air bersih adalah salah satu jenis sumber daya berbasis air yang bermutu baik dan biasa dimanfaatkan oleh manusia untuk dikonsumsi atau dalam melakukan aktivitas sehari-hari. Air minum merupakan air yang dikonsumsi manusia dalam memenuhi kebutuhan cairan tubuh. Mengacu pada Peraturan Menteri Kesehatan Nomor 492 Tahun 2010 tentang Persyaratan Kualitas Air Minum, air minum adalah air yang melalui proses pengolahan atau tanpa proses pengolahan yang memenuhi syarat kesehatan dan dapat langsung diminum. Permenkes tersebut juga menyatakan bahwa penyelenggara air minum wajib menjamin air minum yang diproduksinya aman bagi kesehatan (Kemenkes RI, 2019).

Peraturan Menteri Kesehatan Nomor 492 Tahun 2010 menyatakan bahwa air minum yang aman (layak) bagi kesehatan adalah air minum yang memenuhi persyaratan secara fisik, mikrobiologis, kimia, dan radioaktif. Secara fisik, air minum yang sehat adalah tidak berbau, tidak berasa, tidak berwarna serta memiliki total zat padat terlarut, kekeruhan, dan suhu sesuai ambang batas yang ditetapkan. Secara mikrobiologis, air minum yang sehat harus bebas dari bakteri E.Coli dan total bakteri koliform. Secara kimiawi, zat kimia yang terkandung dalam air minum seperti besi, aluminium, klor, arsen, dan lainnya harus di bawah ambang batas yang ditentukan. Secara radioaktif, kadar gross alpha activity tidak boleh melebihi 0,1 becquerel per liter $(\mathrm{Bq} / \mathrm{l})$ dan kadar gross beta activity tidak boleh melebihi $1 \mathrm{~Bq} / \mathrm{l}$ (Kemenkes RI, 2019).

Data dari BPS (Badan Pusat Statistik) yang dipublikasikan melalui Indikator Perumahan dan Kesehatan Lingkungan 2018, secara nasional menunjukkan sumber air utama yang paling banyak digunakan rumah tangga untuk minum adalah air isi ulang $(26,43 \%)$, sumur terlindung $(17,51 \%)$, dan sumur bor/pompa (16,36\%) (Kemenkes RI, 2019).

Secara nasional persentase rumah tangga dengan akses air minum layak sebesar 73,68\% (Gambar 7.5). Provinsi dengan persentase rumah tangga dengan akses air minum layak tertinggi yaitu Bali $(90,90 \%)$, DKI Jakarta $(89,59 \%)$ dan Kalimantan Utara $(88,30 \%)$. Sedangkan provinsi dengan persentase rumah tangga menurut akses air minum layak terendah adalah Bengkulu (49,37\%), Lampung (56,78\%), dan Papua (58,35\%) (Kemenkes RI, 2019).

Berdasarkan data Kalimantan Selatan didapatkan bahwa cakupan keluarga memiliki akses/menggunakan sarana air bersih sebesar 84,6\% (51.095 keluarga) pada tahun 2017 sedangkan pada tahun 2018 sebesar 84,2\% (374.321 keluarga), berarti secara persentase adanya penurunan keluarga dalam penggunaan sarana air bersih (Pusdatin Kemenkes RI, 2019).

Angka Bebas Jentik (ABJ) secara nasional sebagai salah satu indikator yang digunakan untuk upaya pengendalian penyakit DBD sampai dengan tahun 2018 belum mencapai target program yang sebesar $\geq 95 \%$. ABJ tahun 2018 yang sebesar $31,5 \%$ menurun dibandingkan tahun 2017 sebesar 46,7\%. ABJ merupakan output yang diharapkan dari kegiatan Gerakan 1 Rumah 1 Jumantik (G1R1J). Untuk itu perlu optimalisasi kegiatan tersebut dari seluruh kabupaten/kota, optimalisasi dana DAK untuk pemenuhan kebutuhan logistik yang mendukung pengendalian DBD, serta monitoring dan pembinaan kepada dinas kesehatan provinsi dalam manajemen sistem pelaporan (Kemenkes RI, 2019).

Definisi rumah tangga yang memiliki akses sanitasi layak adalah apabila fasilitas sanitasi yang digunakan memenuhi syarat kesehatan, antara lain 
dilengkapi dengan jenis kloset leher angsa atau plengsengan dengan tutup dan memiliki tempat pembuangan akhir tinja tangki (septic tank) atau Sistem Pengolahan Air Limbah (SPAL), dan merupakan fasilitas buang air besar yang digunakan sendiri atau bersama (Kemenkes RI, 2019).

Secara nasional, terdapat $69,27 \%$ rumah tangga yang memiliki akses terhadap sanitasi layak, provinsi dengan persentase rumah tangga yang memiliki akses terhadap sanitasi layak tertinggi yaitu Bali (91,14\%), DKI Jakarta (90,73\%), dan DI Yogyakarta sebesar $(88,92 \%)$. Sedangkan provinsi dengan persentase rumah tangga yang memiliki akses terhadap sanitasi layak terendah adalah Papua (33,75\%), Bengkulu $(44,31 \%)$, dan Nusa Tenggara Timur $(50,72 \%) \quad$ (Kemenkes RI, 2019).Berdasarkan data Kalimantan Selatan didapatkan bahwa cakupan anggota keluarga tidak ada yang merokok sebesar 54,9\% (33.348 keluarga) pada tahun 2017, sedangkan pada tahun 2018 sebesar 58,2\% (259.118 keluarga), berarti adanya peningkatan persentase yang belum signifikan mengenai cakupan anggota keluarga tidak ada yang merokok (Pusdatin Kemenkes RI, 2019).

Informasi frekuensi dan porsi asupan sayur dan buah dikumpulkan dengan menghitung jumlah hari konsumsi dalam seminggu dan jumlah porsi ratarata dalam sehari. Penduduk dikategorikan 'cukup' mengonsumsi sayur dan/atau buah apabila makan sayur dan/atau buah minimal 5 porsi per hari selama 7 hari dalam seminggu. Dikategorikan 'kurang' apabila konsumsi sayur dan/atau buah kurang dari ketentuan di atas (Balitbangkes Kemenkes RI, 2013).

Berdasarkan dara Riset Kesehatan Dasar tahun 2018 didapatkan bahwa proporsi konsumsi buah/sayur per hari dalam seminggu pada penduduk umur $\geq 5$ tahun menurut provinsi Kalimantan Selatan dengan kategori tidak konsumsi sebesar 19,8\%, kategori 1-2 porsi sebesar $69,5 \%$, kategori 3-4 porsi sebesar 8,9\% sedangkan kategori $\geq 5$ porsi sebesar $1,9 \%$, berarti perilaku konsumsi buah/sayur perhari dalam seminggu pada penduduk umur $\geq 5$ tahun sebagian besar kurang dari ketentuan yang direkomendasikan (Balitbangkes Kemenkes RI, 2018).

Berdasarkan data Riset Kesehatan Dasar tahun 2018 didapatkan bahwa Proporsi Merokok Dalam Gedung/Ruangan pada Penduduk Umur $\geq$ 10 Tahun menurut Provinsi Kalimantan Selatan sebesar $85 \%$. Berdasarkan karakteristik kelompok umur 15-19 tahun didapatkan bahwa proporsi merokok dalam gedung/ruangan sebesar $75,3 \%$ sedangkan kelompok umur 20-24 tahun didapatkan bahwa proporsi merokok dalam gedung/ruangan sebesar $81,2 \%$, berarti sebagian besar kelompok remaja merokok dalam gedung/ruangan.

Berdasarkan uraian data narasi diatas, maka perlunya dilakukan pengabdian kepada masyarakat mengenai "Edukasi 10 indikator Perilaku Hidup Bersih dan Sehat (PHBS) tatanan rumah tangga di SMA KORPRI Banjarmasin Tahun 2020”.

\section{TARGET DAN LUARAN}

Target dalam pengabdian ini adalah meningkatkan pengetahuan siswa mengenai 10 indikator Perilaku Hidup Bersih dan Sehat (PHBS) tatanan rumah tangga sedangkan luarannya adalah publish ke jurnal pengabdian masyarakat.

\section{METODE PELAKSANAAN}

Mekanisme sebelum pelaksanaan penyuluhan terdiridari tahap persiapan yaitu penyusunan preplanning, kontrak waktu \& menyepakati tempat penyuluhan serta mempersiapan media penyuluhan. Metode penyuluhan yang 
dilaksanakan yaitu dengan menggunakan media power poin dalam penyampaian materi mengenai "Edukasi 10 indikator Perilaku Hidup Bersih dan Sehat (PHBS) tatanan rumah tangga", akan tetapi sebelum memulai penyuluhan, dilakukan kegiatan pretest yaitu pengisian kuesioner oleh siswa untuk mengukur atau mengetahui sejauh mana pengetahuan siswa mengenai "10 indikator Perilaku Hidup Bersih dan Sehat (PHBS) tatanan rumah tangga. Proses penyuluhan yang dilaksanakan dengan metode yaitu metode ceramah, metode diskusiserta proses tanya jawab, kemudian setelah diberikan penyuluhan, maka dilakukan posttest yaitu dibagikan kembali kuesioner tersebut untuk diisi kembali oleh siswa, setelah data pengetahuan sebelum dan sesudah penyuluhan sudah didapatkan, maka dilakukan uji statistik menggunakan uji Wilcoxon yang bertujuan untuk mengetahui perbedaan atau mengetahui keefektifan metode penyuluhan yang telah disampaikan.

\section{HASIL DANPEMBAHASAN}

Pelaksanaan Kegiatan pengabdian kepada masyarakat melalui Kegiatan penyuluhan di SMA KORPRI Kota Banjarmasin dengan materi Edukasi 10 indikator Perilaku Hidup Bersih dan Sehat (PHBS) tatanan rumah tangga berlangsung sesuai rencana. Berikut beberapa dokumentasi kegiatan pengabdian masyarakat:

Berdasarkan hasil dari kuesioner mengenai pengetahuan "10 indikator Perilaku Hidup Bersih dan Sehat (PHBS) tatanan rumah tangga di SMA KORPRI Kota Banjarmasin Tahun 2020"yang terdiri dari 21 pertanyaan yang dibagikan kepada objek atau khalayak sasaran yaitu siswa kelas XII SMA KORPRI Kota Banjarmasin sebanyak 26 siswa sebelum dilakukannya penyuluhan melalui media power point (pretest dan ppostest) diperoleh hasil sajikan dalam tabel 1. Selanjutnya dilakukan analisis menggunakan Wilcoxon (tabel 2) hasilnya $p$-value $(0,000)<\alpha(0,05)$ yang artinya secara statistik terdapat perbedaan pengetahuan yang bermakna antara sebelum dan sesudah penyuluhan atau terjadi peningkatkan pengetahuan siswa mengenai "10 indikator Perilaku Hidup Bersih dan Sehat (PHBS) tatanan rumah tangga.

Tabel 1.

Hasil Pengetahuan Sebelum dan Sesudah Penyuluhan

\begin{tabular}{clcc}
\hline No. & Variabel & $\mathrm{n}$ & $\%$ \\
\hline 1. & Pengetahuan (Sebelum Penyuluhan) & 7 & 26,9 \\
& Cukup & 19 & 73,1 \\
& Kurang & 26 & 100 \\
\cline { 2 - 5 } & Jumlah & & \\
\hline 2. & Pengetahuan (Sesudah Penyuluhan) & 21 & 80,8 \\
& Baik & 5 & 19,2 \\
& Cukup & 26 & 100 \\
\cline { 2 - 4 }
\end{tabular}


Tabel 2.

Hasil Analisis Uji Wilcoxon

\begin{tabular}{|c|c|c|c|c|c|}
\hline \multicolumn{2}{|c|}{ Sebelum dan Sesudah Perlakuan } & \multirow{2}{*}{26} & \multirow{2}{*}{$\begin{array}{c}\begin{array}{c}\text { Median } \\
\text { (Minimum-Maksimum) }\end{array} \\
9,00(2-14)\end{array}$} & \multirow{2}{*}{$\begin{array}{c}\text { Mean } \\
9,27\end{array}$} & \multirow{2}{*}{$\begin{array}{c}\begin{array}{c}p- \\
\text { valuc }\end{array} \\
0,000\end{array}$} \\
\hline $\begin{array}{l}\text { Pengetahuan } \\
\text { Penyuluhan(Pretest) }\end{array}$ & Sebelum & & & & \\
\hline $\begin{array}{l}\text { Pengetahuan } \\
\text { Penyuluhan(Posttest) }\end{array}$ & Sesudah & 26 & $17,50(13-20)$ & 17,42 & \\
\hline
\end{tabular}

Power Point merupakan salahsatu program dalam Microsoft Office. Microsoft Office Power Point adalah salah satu jenis program yang tergabung dalam Microsoft office. Microsoft Office Power Point merupakan program aplikasi yang dirancang secara khusus untuk menampilkan program multimedia. Program Microsoft Office Power Point adalah salah satu software yang dirancang khusus untuk mampu menampilkan program multimedia dengan menarik, mudah dalam pembuatan, mudah dalam penggunaan dan relatif murah karena tidak membutuhkan bahan baku selain alat untuk menyimpan data.

Media slide tergolong dalam kelompok gambar diam, tetapi ia termasuk media pandang dengar, media slide mempunyai kemampuan untuk: (1) Memungkinkan penekanan pada impresi fakta-fakta yang baru atau untuk mengembangkan pengertian suatu abstraksi; (2) Dapat merangsang peserta didik untuk meneliti bahanbahan lebih lanjut; (3) Dengan mengadaptasi dan memilih secara tepat, slide dapat membantu untuk menimbulkan pengertian dan ingatan yang kuat, terhadap isi materi; (4) Gambargambar garis yang sederhana, misalnya gambar bagan, sering lebih membuat efektif dalam menyampaikan informasi dari pada dalam gambar foto; (5) Warna gambar dapat membantu untuk membuat daya tarik dalam memberi penekanan pada suatu masalah yang sedang dibicarakan; (6) Bantuan verbal ayau syimbol lainya sebagai alat bantu dalam gambar diam, dapat membantu untuk menimbulkan kejelasan (Daryanto, 2010).
Penyelenggaraan

penyuluhan diharapkan mampu memberikan suatu perubahan sosial baik pada individu maupun masyarakat agar dapat terwujud perubahan yang lebih baik sesuai dengan yang diharapkan. Dari pelaksanaan penyuluhan tersebut diharapkan masyarakat mampu mendapatkan atau mengembangkan pengetahuan, keterampilan serta perilakunya maupun keluarganya. Oleh karena itu, proses dan penyelenggaran penyuluhan harus dibuat sedemikian rupa agar masyarakat mau, mampu, tertarik, dan ikut serta dalam penyelenggaraan penyuluhan sehingga mampu mewujudkan harapan yang diinginkan (Leilani dkk., 2015).

Salah satu unsur penting yang perlu diperhatikan dalam penyelenggaraan penyuluhan adalah pemilihan Media penyuluhan. Dimana media penyuluhan merupakan segala sesuatu yang berisi pesan atau informasi yang dapat membantu kegiatan penyuluhan. Media penyuluhan perikanan digunakan dalam rangka mengefektifkan penyampaiaan pesan pada proses komunikasi antara penyampai pesan dengan masyarakat sasaran penyuluhan.Penggunaan media setidaknya mampu memberikan banyak manfaat seperti; mempermudah dan mempercepat sasaran dalam menerima pesan, mampu menjangkau sasaran yang lebih luas, alat informasi yang akurat dan tepat, dapat memberikan gambaran yang lebih kongkrit, baik unsur gambar maupun geraknya, lebih atraktif dan komunikatif, dapat menyediakan lingkungan belajar yang amat mirip dengan lingkungan kerja sebenarnya, memberikan stimulus terhadap banyak 
indera, dapat digunakan sebagai latihan kerja dan latihan simulasi (Leilani dkk., 2015).

Menurut Muhroghibi (2001) dalam Prasetyo (2013), power point merupakan salah satu alat peraga yang berfungsi sebagai alat bantu untuk memaparkan atau mempresentasikan sebuah materi (gizi). Keunggulan power point antara lain: materi menjadi lebih menarik karena ada permainan warna, huruf dan animasi, baik animasi teks maupun animasi gambar atau foto. Pesan informasi secara visual mudah dipahami peserta didik, dan lebih merangsang anak untuk mengetahui lebih jauh informasi tentang bahan ajar yang tersaji.

Penggunaan media pembelajaran (dalam hal ini power point) dapat membuat siswa-siswa lebih aktif dan antusias, hal ini sesuai dengan pendapat Sudjana dan Ahmad Rivai (2001) dalam Prasetyo (2013), yang mengungkapkan bahwa manfaat media dalam peroses pengajaran diantaranya ialah pengajaran akan menarik perhatian para siswa sehingga dapat menimbulkan motivasi belajar siswa, bahan ajar akan lebih jelas maknanya sehingga dapat lebih mudah dipahami oleh siswa, dan siswa lebih memahami atau menguasai tujuan dari pembelajaran yang lebih baik. Metode pembelajaran denganmedia akan lebih bervariasi karena tidak semata-mata komunikasi verbal melalui penuturan katakata oleh guru sehingga siswa tidah mudah bosan.

Media merupakan salah satu faktor penentu keberhasilan pembelajaran. Melalui media proses pembelajaran bisa lebih menarik dan menyenangkan (joyfull learning). Aspek penting lainnya penggunaan media adalah membantu memperjelas pesan pembelajaran. Informasi yang disampaikan secara lisan terkadang tidak dipahami sepenuhnya, terlebih apabila kurang cukup dalam menjelaskan materi. Disinilah peran media, sebagai alat bantu memperjelas pesan pembelajaran (Hamtiah,2012 dalam Priyani, 2015).

$$
\text { Penelitian Prasetyo }
$$

menunjukkan bahwa uji statistik dengan menggunakan uji Paired Samples Test untuk pengetahuan gizi sebelum dan sesudah diberi penyuluhan tentang gizi dengan menggunakan media power point. Hasil uji menunjukkan nilai $\mathrm{p}<0,05$ artinya ada perbedaan pengetahuan gizi sebelum dan sesudah diberi penyuluhan tentang gizi dengan menggunakan media power point.

Hasil penelitian ini sesuai dengan teori yang dikemukakan oleh Sadiman dkk, (2002) dalam Sulistyawati (2014) yang menyatakan bahwa slide power point adalah suatu multimedia yang merupakan alat bantu visual yang biasa digunakan untuk bermacam-macam bentuk media antara lain teks, grafik, gambar dan lain-lain sehingga proses pengajaran lebih interaktif.

Hasil penelitian yang dilakukan oleh Wijayanti dkk (2016) menyatakan bahwa penyuluhan berupa ceramah dengan power point menggunakan media LCD berhasil meningkatkan pengetahuan masyarakat tentang leptospirosisdi Kecamatan Tembalang, Kota Semarang Jawa Tengah.

Berdasarkan hasil penelitian oleh

Rusdi dan Habibi menggunakan uji statisitik wilcoxon yang telah dilakukan, diperoleh $p$-value $0,000(<0,05)$, sehingga menunjukkan media slide presentasi berpengaruh dalam menunjang peningkatan pengetahuan tentang gerakan shodaqoh sampah muhammadiyah pada siswa kelas V SD Muhammadiyah 4 Samarinda Kalimantan Timur.

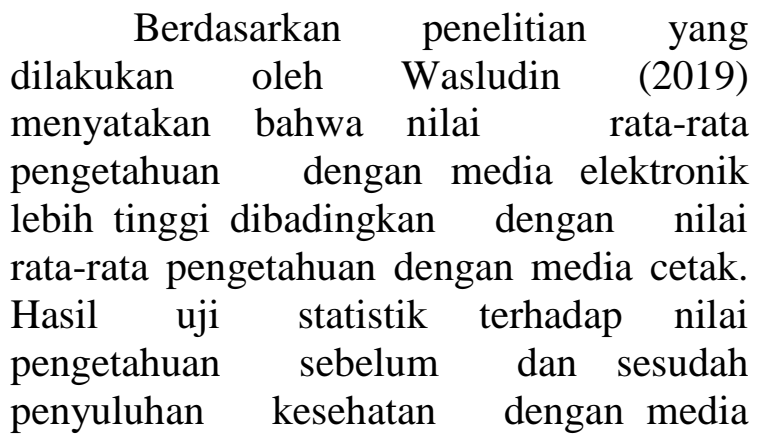


elektronik diperoleh nilai $\mathrm{p}=0.000$, maka dapat disimpulkan ada perbedaan yang signifikan antara nilai pengetahuan sebelum dan sesudah dilakukan penyuluhan kesehatan dengan menggunakan media elektronik.

Faedah penggunaan media yakni mendorong keinginan orang untuk mengetahui, kemudian lebih mendalami, dan akhirnya memberikan pengertian yang lebih baik (Mahfoedz, 2007 dalam Wijayanti, dkk., 2016). Green dan Kreuter menyatakan bahwa pengetahuan adalah suatu hasil dari tahu, yang terjadi setelah individu melakukan penginderaan terhadap objek tertentu. Hasil dan bukti belajar adalah adanya perubahan dari tidak tahu menjadi tahu, dan dari tidak mengerti menjadi mengerti. Keberhasilan (Nurlaela, 2014 dalam Wijayanti, dkk., 2016).

Pengetahuan merupakan hasil dari tahu dan terjadi setelah orang melakukan penginderaan terhadap suatu objek tertentu. Penginderaan terjadi melalui pancaindera manusia yakni indera penglihatan, pendengaran, penciuman, rasa dan raba. Notoatmodjo menyimpulkan dari penelitian para ahli, bahwa indra yang paling banyak menyalurkan pengetahuan ke dalam otak adalah mata (indera penglihatan). Kurang lebih $75-87 \%$ pengetahuan manusia diperoleh dan disalurkan oleh mata, sedangkan 13\%-25 \% oleh indera lainnya (Yustisa dkk., 2014).

Berdasarkan hasil yang ditelah didapatkan dan membandingkan hasil yang sebelumnya serta berdasarkan teori yang ada membuktikan bahwa penggunaan media power point dalam mentransformasi pengetahuan sangat efektif yang dapat dilihat dari hasil statistik yaitu adanya perbedaan rata-rata skor pengetahuan sebelum dan sesudah penyuluhan pada siswa di SMA KORPRI kota Banjarmasin, dimana dapat digunakan sebagai salah satu indikator keberhasilan dalam kegiatan penyuluhan yang telah dilakukan, selain itu juga adanya bentuk apresiasi dan tanggapan yang positif dari siswa serta kepala sekolah mengenai kegiatan penyuluhan "10 indikator Perilaku Hidup Bersih dan Sehat (PHBS) tatanan rumah tangga.

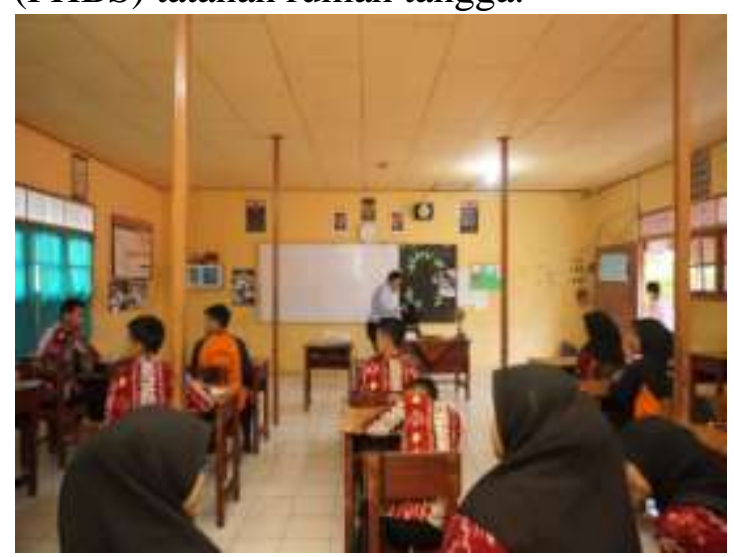

Gambar 1. Persiapan Penyuluhan

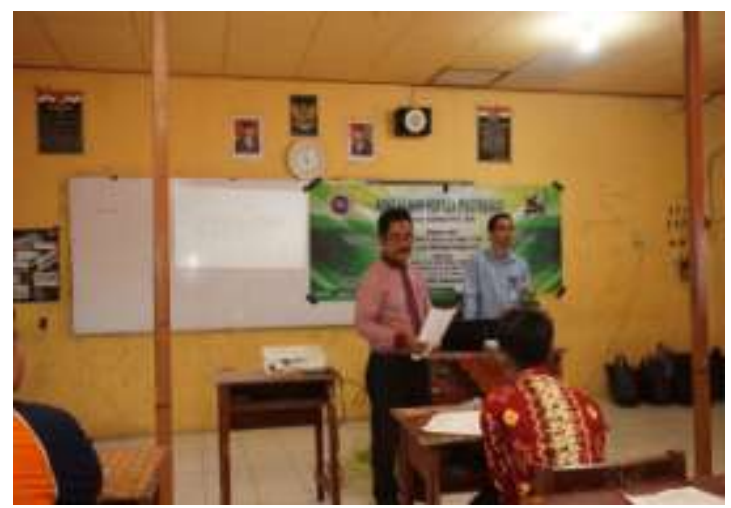

Gambar 2. Perkenalan dan Penjelasan Kuesioner

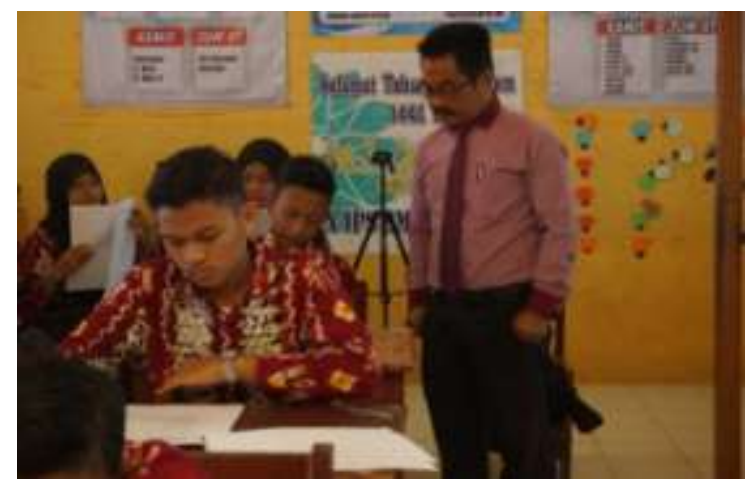

Gambar 3. Kegiatan Pretest 


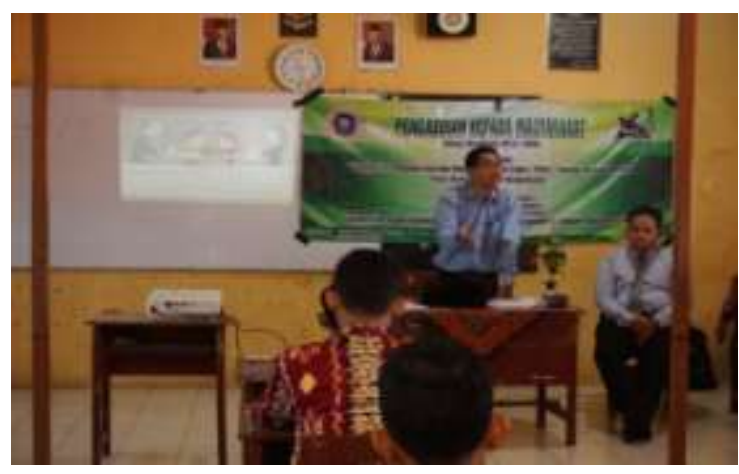

Gambar 4. Kegiatan Penyuluhan

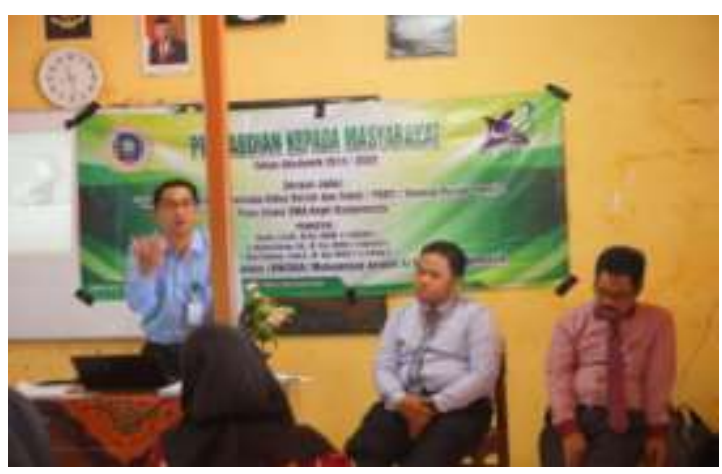

Gambar 5. Kegiatan Penyuluhan

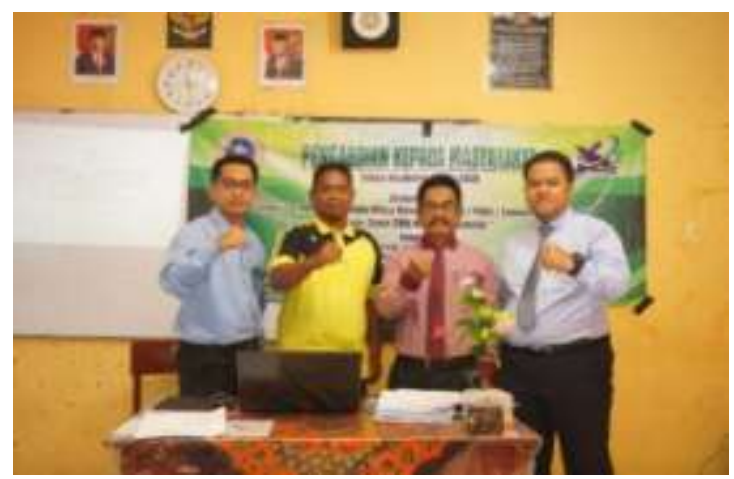

Gambar 6. Foto bersama

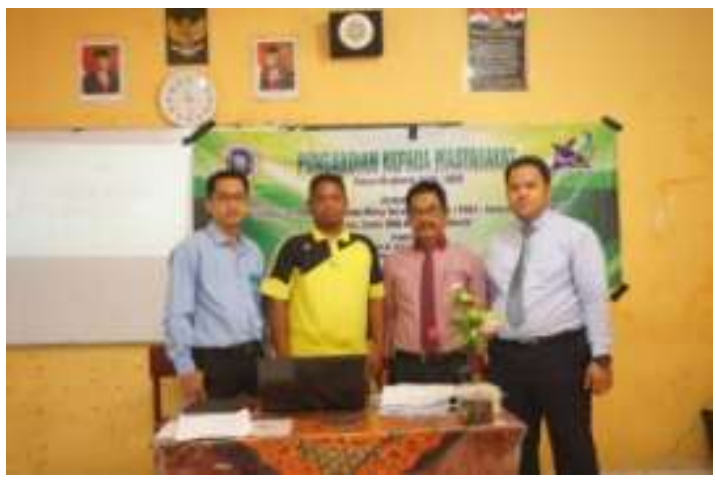

Gambar 7. Foto bersama

\section{KESIMPULAN DAN SARAN}

\section{Kesimpulan}

Berdasarkan hasil kegiatan pengabdian di SMA KORPRI kota Banjarmasin menunjukkan bahwa p-value $(0,000)<\alpha \quad(0,05)$ yang artinya secara statistik terdapat perbedaan pengetahuan yang bermakna antara sebelum dan sesudah penyuluhan menggunakan media power point, dengan demikian dapat disimpulkan bahwa metode penyuluhan menggunakan media power point yang dilakukan di SMA KORPRI kota Banjarmasin mampu dan berhasil meningkatkan pengetahuan siswa mengenai"10 indikator Perilaku Hidup Bersih dan Sehat (PHBS) tatanan rumah tangga.

\section{Saran}

Disarankan agar pihak sekolah dapat bekerjasama dengan pihak Puskesmas yang ada di wilayah tersebut dalam rangka memberdayakan UKS untuk dapat mendidik anggota UKS yang bertugas dalam memberikan edukasi kesehatan menggunakan media, khususnya media power point agar dapat membantu memberikan pemahaman bagi siswa yang lainnya mengenai kesehatan secara komprehensif melalui UKS di SMA KORPRI kota Banjarmasin.

\section{UCAPAN TERIMA KASIH}

Penulis mengucapkan terima kasih kepada Lembaga Penelitian dan Pengabdian pada Masyarakat (LP2M) Universitas Islam Kalimantan Muhammad Arsyad Al Banjari Banjarmasindan Kepala Sekolah SMA KORPRI Kota Banjarmasin yang telah memberikan izin untuk melaksanakan kegiatan pengabdian masyarakat serta seluruh dewan guru yang telah membantu dalam kegiatan Pengabdian Masyarakat ini.

\section{DAFTAR PUSTAKA}

Badan Penelitian dan Pengembangan Kesehatan (Balitbangkes), Kemenkes RI., 2013. Riset 
Kesehatan Dasar (RISKESDAS 2013). Jakarta : Balitbangkes Kemenkes.[Online].http://www.dep kes.go.id/resources/download/gener al/Hasil\%20Riskesdas\%202013.pdf. [diakses tanggal 14 Februari 2020].

Badan Penelitian dan Pengembangan Kesehatan (Balitbangkes), Kemenkes RI., 2018. Riset Kesehatan Dasar (RISKESDAS 2018). Jakarta : Balitbangkes Kemenkes.[Online].http://www.dep kes.go.id/resources/download/infoterkini/materi_rakorpop_2018/Hasil \%20Riskesdas\%202018.pdf. [diakses tanggal 14 Februari 2020].

Daryanto. 2010. Media Pembelajaran Perannya Sangat Penting Dalam Mencapai Tujuan Pembelajaran. Yogyakarta: Gava Media.

Hs, Hastaty., Lubis, Zulhaida \& Jumirah., 2015. Perilaku Kader dalam Pemantauan Pertumbuhan Balita di Puskesmas Mandala Kecamatan Medan Tembung. [Online]. https://media.neliti.com/media/publi cations/14556-ID-perilaku-kaderdalam-pemantauan-pertumbuhanbalita-di-puskesmas-mandalakecamata.pdf. [diakses tanggal 14 Februari 2020].Riyana, Ilyasih. 2008. Pemanfaatan OHP dan Presentasi Dalam Pembelajaran. Jakarta: Cipta Agung.

Kemenkes RI, 2019. Profil Kesehatan Indonesia Tahun 2018.Jakarta : Kementerian

KesehatanRI.[Online].https://pusdati n.kemkes.go.id/resources/download/ pusdatin/profil-kesehatanindonesia/PROFIL_KESEHATAN_ 2018_1.pdf. [diakses tanggal 14 Februari 2020].

Leilani, Ani., Nurmalia, Nayu., Patekkai, Muh., 2015. Jurnal Penyuluhan Kelautan dan Perikanan Indonesia. Efektivitas Penggunaan Media Penyuluhan (Kasus pada Kelompok
Ranca Kembang Desa Luhur Jaya Kecamatan Cipanas Kabupaten Lebak Provinsi Banten). Vol. 9, No. 1 Juni 2015. [Online]. http://jppik.id/index.php/jppik/articl e/viewFile/79/74. [diakses tanggal 14 Februari 2020].

Prasetyo, Muhammad Sigit., 2013. Naskah Publikasi. Perbedaan Pengetahuan Sebelum dan Sesudah diberi Penyuluhan Gizi Menggunakan Media Power Point di SD Negeri Karangasem III Surakarta. [Online]. http://eprints.ums.ac.id/27250/15/Na ska_Publikasi_ilmiah.pdf. [diakses tanggal 14 Februari 2020].

Priyani, Elis Siti., 2015. Naskah Publikasi. Pengaruh Penyuluhan Media Powerpoint Dan Mediavideo Terhadap Tingkat Pengetahuan Ibu Tentang Kontrasepsi Iud Pasca Plasenta Di Puskesmas Kasihan I Bantul. Program Studi Bidan Pendidik Jenjang D IV Sekolah Tinggi Ilmu Kesehatan 'Aisyiyah Yogyakarta. [Online] http://digilib.unisayogya.ac.id/431/1 /Naskah\%20publikasi.pdf. [diakses tanggal 14 Februari 2020].

Pusdatin Kemenkes RI, 2019. Power Point Persentation: Profil Keluarga Sehat Indonesia. [Online]. https://pusdatin.kemkes.go.id/resour ces/download/pusdatin/lainlain/Profil-KeluargaSehat_Indonesia_dan_Provinsi-Jan2019.pdf. [diakses tanggal 14 Februari 2020].

Rahman, Abd., 2016. Jurnal Kesehatan Tadulako. Hubungan Pengetahuan dan Sikap Ibu dengan Pertolongan Persalinan pada Tenaga Kesehatan di Desa Lolu Kecamatan Biromaru Kabupaten Sigi. Vol. 2, No. 2 Juli 2016.

[Online]. http://jurnal.untad.ac.id/jurnal/index. php/HealthyTadulako/article/view/8 
328. [diakses tanggal 14 Februari 2020].

Risnawaty, Gracia., 2016. Jurnal Promkes. Faktor Determinan Perilaku Cuci Tangan Pakai Sabun (CTPS) Pada Masyarakat di Tanah Kalikedinding. Vol. 4, No. 1 Juli $2016 . \quad$ [Online]. https://ejournal.unair.ac.id/PROMKES/articl e/view/5807. [diakses tanggal 14 Februari 2020].

Rusdi., Habibi, Muhammad., 2018. Pendidikan Lingkungan dan Pembangunan Berkelanjutan. Pengaruh Media Slide Presentasi dalam Menunjang Peningkatan Pengetahuan Tentang Gerakan Shodaqoh Sampah Muhammadiyah pada Siswa Kelas $V \quad S D$ Muhammadiyah 4 Samarinda Kalimantan Timur. Vol. XIX, No. 2 September 2018.

Sulistyawati, Nur Dani., 2014. Efektifitas Alat Bantu Penyuluhan Slide Power Pointdengan Leaflet tentang Kanker Servik Terhadap Sikap WUS dalamPemeriksaan IVA di Desa Jatimulyo Dlingo Bantul Tahun 2014. Program Studi Bidan Pendidik Jenjang D IV, Sekolah Tinggi Ilmu Kesehatan'Aisyiyah Yogyakarta. [Online]. Available from:http://digilib.unisayogya.ac.i d/1128/1/NASKAH\%20PUBLIKA SI.pdf.[diakses tanggal 14 Februari 2020].

Wasludin, 2019. Jurnal Medikes (Media Infromasi Kesehatan). Efektifitas Media Elektronik Dan Media Cetak Terhadap Pengetahuan Hiv/Aids Pada Siswa Smp Negeri 4 Kota Tangerang. Vol. 6, No. 1. [Online]. https://jurnal.poltekkesbanten.ac.id/ Medikes/article/view/90. [diakses tanggal 14 Februari 2020].

Wijayanti, Tri., Isnani, Tri., Kesuma, Agung Puja., 2016., BALABA :
Jurnal Litbang Pengendalian Penyakit Bersumber Binatang Banjarnegara. Pengaruh Penyuluhan (Ceramah dengan Power Point) terhadap Pengetahuan tentang Leptospirosis di Kecamatan Tembalang, Kota Semarang Jawa Tengah. Vol. 12, No. 1, Juni 2016. [Online].

https://media.neliti.com/media/publi cations/57729-ID-pengaruh-

penyuluhan-ceramah-denganpower.pdf. [[diakses tanggal 14 Februari 2020].

Yusrina, Arifa., Devy, Shrimarti Rukmini., 2016. Jurnal Promkes. Faktor Yang Mempengaruhi Niat Ibu Memberikan ASI Eksklusif di Kelurahan Magersari, Sidoarjo. Vol. 4, No. 1 Juli 2016. [Online]. https://ejournal.unair.ac.id/PROMKES/articl e/view/5802. [diakses tanggal 14 Februari 2020].

Yustisa, Putu Fanny., Aryana, I Ketut., Suyasa, I Nyoman Gede., 2014. Jurnal Kesehatan Lingkungan. Efektifitas penggunaan media cetak dan media elektronika dalam promosi kesehatan terhadap peningkatan pengetahuan dan perubahan sikap siswa SD. Vol. 4, No. 1, Mei 2014. 